\title{
HARMONISASI SAK DAN ATURAN PAJAK: MUNGKINKAH?
}

\author{
Heri Sukendar W \\ Accounting Department, Faculty of Economic and Communication, BINUS University \\ Jln. K.H. Syahdan No. 9, Palmerah, Jakarta Barat 11480 \\ heris1024@yahoo.com
}

\begin{abstract}
This paper is intended to illustrate the fact that the case today, especially in Indonesia's commitment to convergency of IFRS, where the decision was certainly not out of global importance that in order to improve the information from the financial statements of companies in Indonesia. In addition, the IFRS Convergence is one of the Indonesian government agreements as a member of the G20 forum, the results of the meeting of G20 leaders in Washington DC forum, 15 November 2008. On the other hand, the tax rules that apply are still using the old accounting standards and do not follow the development of increasingly different. Previous differences between GAAP and tax rules are limited to the "deductible and non-deductible" which is resolved through fiscal reconciliation mechanism with positive correction and correction negatipnya. The widening gap today would be a separate issue for IAI as the organization of the accounting profession. Tax Accountant compartment formation in March 2014 is a serious evidence of the organization as an anticipation, particularly in an effort to bridge the gap widening
\end{abstract}

Keywords: SAK, IFRS, tax law, fair value, historical value

\begin{abstract}
ABSTRAK
Tulisan ini ditujukan untuk menggambarkan fakta yang terjadi saat ini, khususnya dalam komitmen Indonesia untuk melakukan konvergensi IFRS. Keputusan itu tentunya tidak lepas dari kepentingan global, yaitu agar dapat meningkatkan daya informasi dari laporan keuangan perusahaan-perusahaan di Indonesia. Di samping itu konvergensi IFRS adalah salah satu kesepakatan pemerintah Indonesia sebagai anggota forum G20, hasil dari pertemuan pemimpin negara forum G20 di Washington DC, 15 November 2008. Di lain pihak aturan pajak yang berlaku masih menggunakan standar akuntansi yang lama dan tidak mengikuti perkembangan yang makin lama makin berbeda. Sebelumnya perbedaan antara SAK dan aturan pajak terbatas pada "deductible dan nondeductible" yang diselesaikan melalui mekanisme rekonsiliasi fiskal dengan koreksi positif dan koreksi negatif. Jurang yang makin lebar saat ini tentunya menjadi permasalahan tersendiri bagi IAI sebagai organisasi dari profesi akuntan. Pembentukan Kompartemen Akuntan Pajak pada Maret 2014 merupakan bukti serius dari organisasi untuk mengantisipasi perbedaan tersebut khususnya dalam upaya menjembatani perbedaan yang makin melebar.
\end{abstract}

Kata kunci: SAK, IFRS, aturan pajak, fair value, historical value 


\section{PENDAHULUAN}

Indonesia sebagai kekuatan ekonomi dunia yang mumpuni, berupaya mempetahankan dan meningkatkan daya saingnya di dunia Internasional. Konvergensi IFRS yang dilakukan Indonesia tentu tidak lepas dari kepentingan global yaitu agar dapat meningkatkan daya informasi dari laporan keuangan perusahaan-perusahaan di Indonesia. Di samping itu, konvergensi IFRS adalah salah satu kesepakatan pemerintah indonesia sebagai anggota G20 forum. Hasil dari pertemuan pemimpin negara G20 pada forum di Washington DC, 15 November 2008, secara prinsip-prinsip G20 yang dicanangkan sebagai berikut: strengthening transparency and accountability, enhancing sound regulation, promoting integrity in financial markets, reinforcing international cooperation, dan reforming international financial institutions.

Pada Desember 2008, Ikatan Akuntan Indonesia (IAI) telah mencanangkan konvergensi PSAK ke IFRS secara penuh pada 2012. Sejak 2009, Dewan Standar Akuntansi Keuangan - Ikatan Akuntan Indonesia (DSAK-IAI) melaksanakan program kerja terkait dengan proses konvergensi tersebut sampai dengan 2011. Ditargetkan bahwa pada 2012, seluruh PSAK tidak memiliki beda material dengan IFRS yang berlaku per 1 Januari 2009. Setelah 2012, PSAK akan di-update secara terus-menerus seiring adanya perubahan pada IFRS. Bukan hanya mengadopsi IFRS yang sudah terbit, DSAK-IAI juga bertekad untuk berperan aktif dalam pengembangan standar akuntansi dunia.

International Financial Reporting Standards (IFRS) memang merupakan kesepakatan global standar akuntansi yang didukung oleh banyak negara dan badan-badan internasional di dunia. Popularitas IFRS di tingkat global makin meningkat dari waktu ke waktu. Kesepakatan G-20 di Pittsburg pada 24-25 September 2009, misalnya, menyatakan bahwa otoritas yang mengawasi aturan akuntansi internasional harus meningkatkan standar global pada Juni 2011 untuk mengurangi kesenjangan aturan di antara negara-negara anggota G-20.

Terlepas dari tren pengadopsian IFRS tersebut, suatu keharusan untuk mempertanyakan secara kritis, apa sesungguhnya hakikat dari konvergensi. Melalui partisipasi global, IFRS memang diharapkan menjadi standar akuntansi berbasis teori dan prinsip yang memiliki kualitas tinggi. Penerapan standar akuntansi yang sama di seluruh dunia juga akan mengurangi masalah-masalah terkait daya banding (comparability) dalam pelaporan keuangan. Yang paling diuntungkan sudah jelas adalah investor dan kreditor transnasional serta badan-badan internasional.

Pengaruh konvergensi IFRS tidak hanya berpengaruh terhadap dunia bisnis saja, tetapi juga dalam dunia Perpajakan. Perbedaan IFRS dengan perpajakan salah satunya mencakup aset tetap (PSAK No. 16). Berdasarkan PSAK No. 16 (Revisi 2007) perusahaan diperbolehkan memilih metode biaya atau metode revaluasi, sedangkan Peraturan Perpajakan, yaitu Peraturan Menteri Keuangan No.79/PMK.03/2008, metode penyusutan aset tetap menggunakan biaya perolehan sesuai Pasal 10 ayat (1) UU PPh, Menteri Keuangan. Masalah kewajiban perpajakan yang timbul atas revaluasi aset tetap adalah sebagai berikut. Pertama, nilai hasil revaluasi akan lebih tinggi dari nilai perolehan awal. Hal ini disebabkan penilaian aset tetap dilakukan berdasarkan nilai pasar/nilai wajar tersebut yang ditetapkan oleh jasa penilai/appraisal independen yang disahkan oleh Menkeu. Sehingga atas hasil revaluasi ini akan muncul selisih revaluasi aset tetap dari perolehan yang lama. Kedua, hasil revaluasi dikenakan PPh bersifat final sebesar $10 \%$ sesuai dengan ketentuan dimaksud pada pasal 5 PMK 79/PMK.03/2008 tentang penilaian kembali aktiva tetap perusahaan untuk tujuan perpajakan. Adapun tatacaranya dapat dilihat pada Per-12/PJ/2009. Objek yang dikenakan tarif $10 \%$ tersebut adalah selisih dari nilai hasil revaluasi aset tetap.

Contoh lainnya yang menjadi perhatian bagi pihak otoritas pajak, konvergensi IFRS yang berimplikasi dengan perpajakan adalah sebagai berikut. Pada PSAK No. 1, pos-pos dalam laporan laba 
rugi komprehensif, yaitu: beban keuangan, keuntungan atau kerugian dari operasi yang dihentikan, diakui secara keseluruhan sedangkan pada perpajakan dilakukan koreksi fiskal atas perbedaan antara akuntansi dan Undang-Undang Pajak Penghasilan. Pada No. PSAK 7, pengungkapan pihak pihak yang memiliki hubungan istimewa adalah pihak istimewa yang terkait dengan pihak dalam transaksi yang wajar, pengakuan beban selama periode berjalan, klasifikasi pengungkapan atas pihak-pihak yang mempunyai hubungan istimewa. Pada nama entitas induk, jika berbeda dengan entitas anak dan pihak yang mengendalikan. Jika entitas induk maupun pihak pengendali utama menghasilkan laporan keuangan yang tersedia untuk keperluan umum, nama entitas induk berikutnya yang paling pertama melakukannya juga harus diungkapkan. Dari sisi perpajakan semua pihak istimewa harus diungkapkan dengan pengisian lampiran 3A atau 3B pada SPT PPh badan dan membuat TP Documentation sesuai Per/43/PJ/2010. Pada PSAK No. 10, pengaruh perubahan nilai tukar valuta asing, pada laporan keuangan mata uang yang digunakan adalah: mata uang fungsional digunakan sebagai mata uang pengukuran dan penyajian bisa berlainan dengan mata uang fungsional. Sedangkan pada perpajakan harus menggunakan rupiah atau US Dollar. Pada PSAK No. 13, properti yang digunakan pada operating lease diklasifikasikan dan dicatat sebagai properti investasi, hanya jika sesuai dengan definisi dari properti investasi dan lessee menggunakan fair value model. Sedangkan pada perpajakan Tidak membedakan properti investasi dari aktiva tetap, Pengalihan tanah dan/bangunan dikenakan pajak penghasilan final.

Berdasarkan latar belakang yang telah diuraikan, maka penelitian tentang harmonisasi SAK dan aturan pajak dilakukan.

\section{METODE}

Dalam mengkaji masalah nilai wajar, penelitian ini menggunakan metode literatur sebagai acuan kajian. Penelitian dengan metode ini merupakan analisis terhadap konsep. Analisis konsep merupakan pembuatan eksistensi dan frekuensi konsep yang biasanya dipresentasikan dalam bentuk kata-kata dalam frasa yang terdapat dalam teks (dalam hal ini berupa literatur). Fokus analisis ini ditujukan pada pengamatan terhadap permasalahan perbedaan antara SAK dengan perturan perpajakan yang merupakan fenomena kendala bagi entitas usaha di Indonesia yang akhir-akhir ini yang dianggap penting dan mendukung tujuan penelitian.

Sebagai tolok ukurnya, penulis menggunakan beberapa acuan pustaka seperti buku IFRS (2010) yang menjelaskan konsep-konsep dasar pelaporan akuntansi standar internasional, memetakan masalah-masalah yang dihadapi dan menguraikan upaya-upaya untuk mengatasi masalah penghitungannya. Atas dasar buku acuan tersebut yang merupakan konsep akuntansi modern diuraikan definisi, manfaat, pengukuran, pengakuan, pelaporan, dan pengungkapan atas penerapan konsep nilai wajar secara sederhana.

\section{PEMBAHASAN}

Pernyataan Standar Akuntansi Keuangan (PSAK) yang telah konvergen dengan IFRS merupakan pedoman pengelolaan keuangan bagi semua entitas di Indonesia. Buku-buku pegangan di SMK dan perguruan tinggi semuanya sudah disesuaikan dengan SAK yang paling mutakhir. Pasal 28 UU pajak nomor 28 tahun 2007 tentang Ketentuan Umum Perpajakan (KUP) menyebutkan bahwa pembukuan harus diselenggarakan dengan cara atau sistem yang lazim dipakai di Indonesia yang dalam hal ini adalah sesuai dengan SAK. 
Pengembangan SAK yang dilakukan di dunia ini melalui IFRS dilakukan secara masif dalam rangka mengikuti perkembangan global yang menuntut kompetisi dan keterbukaan yang semakin transparan dengan tujuan meningkatkan perekonomian global secara sehat dan bertanggung jawab. Perkembangan SAK tersebut nampaknya tidak diikuti oleh aturan pajak yang masih bersifat tradisional, hal ini mengakibatkan perbedaan yang semakin melebar dan signifikan. Perbedaanperbedaan ini adalah sebagai berikut seperti pada Gambar 1.

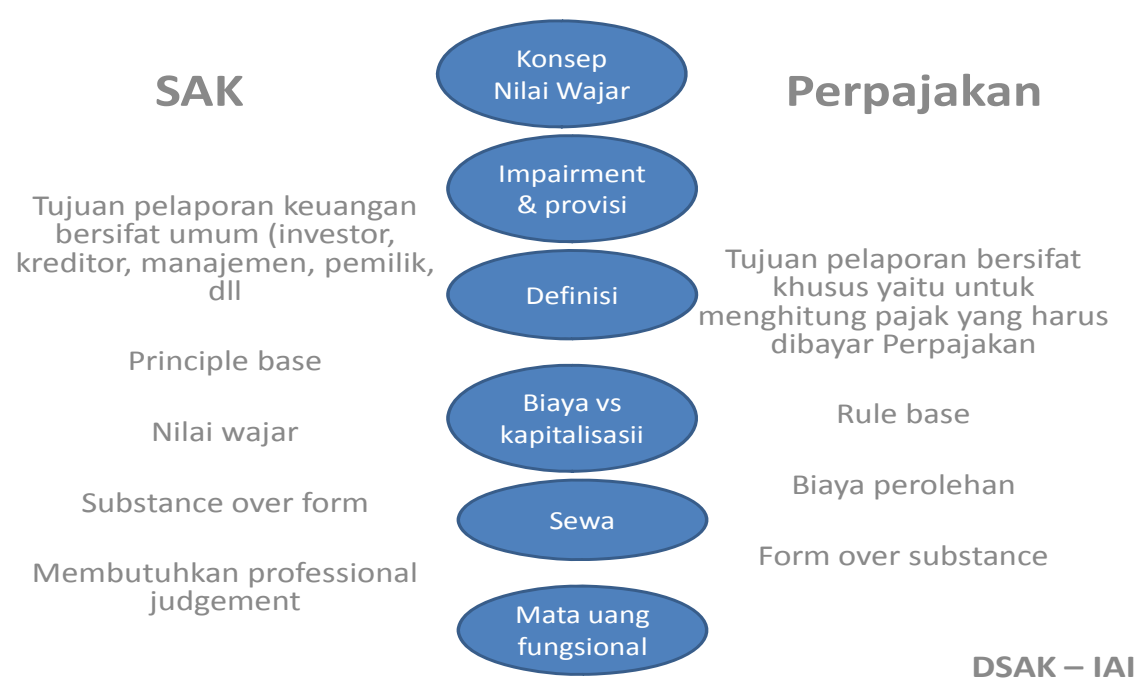

Gambar 1 Contoh Potensi Perbedaan SAK dan Peraturan Perpajakan

(Ikatan Akuntan Indonesia, 2014:34)

Menurut Rosita Uli Sinaga ketua DSAK-IAI (Ikatan Akuntan Indonesia, 2014), gap yang ada saat ini antara SAK dan Aturan Perpajakan cukup besar dan relatif kontradiktif satu sama lain. Lanjutnya: "Memang di negara lain tidak ada yang sama mencapai 100 persen, tapi saya lihat ada halhal yang secara konseptual dapat diminimalisasi perbedaannya." Dikatakannya lagi bahwa fungsi currency walaupun sudah ada kebijakan penggunaaan US Dollar (US) dalam pelaporan keuangan, banyak juga perusahaan Indonesia, misalnya di daerah Batam dan beberapa daeah lain, yang menggunakan Singapore Dollar (SGD) dan tidak terakomodasi.

\section{Nilai Wajar}

Nilai wajar (fair value) selama ini merupakan satu hal yang cukup krusial dan membutuhkan harmonisasi. Saat ini dalam SAK dan perpajakan terdapat perbedaan yang mendasar. Di SAK untuk opsi pengukuran diakui menggunakan model harga pasar atau nilai wajar, sementara di lain pihak yakni di perpajakan secara umum masih mengunakan biaya perolehan (historical cost).

Dalam PSAK No. 68 mengenai "Pengukuran Nilai Wajar", definisi dari nilai wajar adalah harga yang akan diterima untuk menjual suatu aset atau harga yang akan dibayar untuk mengalihkan suatu liabilitas dalam transaksi teratur antara pelaku pasar pada tanggal pengukuran. Menurut Rosita, berdasarkan PSAK 68 ini dalam sebuah transaksi pengukuran yang digunakan adalah berdasarkan market view. Jadi jika antara A dan B bertransaksi, view itu bukan dari view masing-masing orang namun justru lebih kepada market view. Definisi market sendiri sangat jelas, yaitu market yang principal, bahwa barang itu dijual di forum yang paling likuid. Sementara dalam UU No. 7 tahun 1983 sebagaimana telah diubah dalam UU nomor 36 tahun 2008 tentang Pajak Penghasilan, disebutkan 
dalam pasal 10 bahwa harga perolehan atau harga penjualan dalam hal terjadi jual beli harta yang tidak dipengaruhi hubungan istimewa sebagaimana yang termasud dalam pasal 18 ayat 4 adalah jumlah yang sesungguhnya yang dikeluarkan atau diterima. Sedangkan apabila terdapat hubungan hubungan instimewa adalah jumlah yang seharusnya dikeluarkan atau diterima.

Dalam penjelasan pasal 10 ayat 1 di UU PPh tersebut ditegaskan bahwa pada umumnya dalam jual beli harta, harga perolehan harta bagi pihak pembeli adalah harga yang sesungguhnya dibayar. Sedangkan harga penjualan bagi pihak penjual adalah harga yang sesungguhnya diterima. Penetapan fair value dalam hal ini tidak mutlak karena masih ada opsi yang membolehkan memakai historical cost atau fair value (tidak mandatory).

Opsi pilihan antara historical cost dengan fair value tidak bisa diperdebatkan khususnya dalam pengukuran untuk instrument keuangan yang diperdagangkan, misalnya membeli saham yang keesokan harinya dijual kembali atau membeli surat berharga obligasi yang tidak akan ditahan sampai tanggal jatuh tempo. Perkiraan-perkiraan ini harus menggunakan hokum fair value namun aturan perpajakan masih menggunakan historical value.

Atas dasar itu perlu sekali dilakukan edukasi dan sosialisasi SDM dari DJP serta revisi peraturan perpajakan dalam level pengaturan yang dapat diubah, misalnya dalam bentuk PMK dan sebagainya, juga memperjelas hal-hal yang belum diatur dalam perturan perpajakan serta membentuk forum untuk membahas isu perpajakan terkait dengan perubahan dan revisi SAK antara DJP, DSAK, IAI preparer, dan IAI-KAPj. Tabel 1 adalah contoh potensi perbedaan antara PSAK dengan peraturan perpajakan.

Tabel 1 Contoh Potensi Perbedaan antara PSAK dengan Peraturan Perpajakan

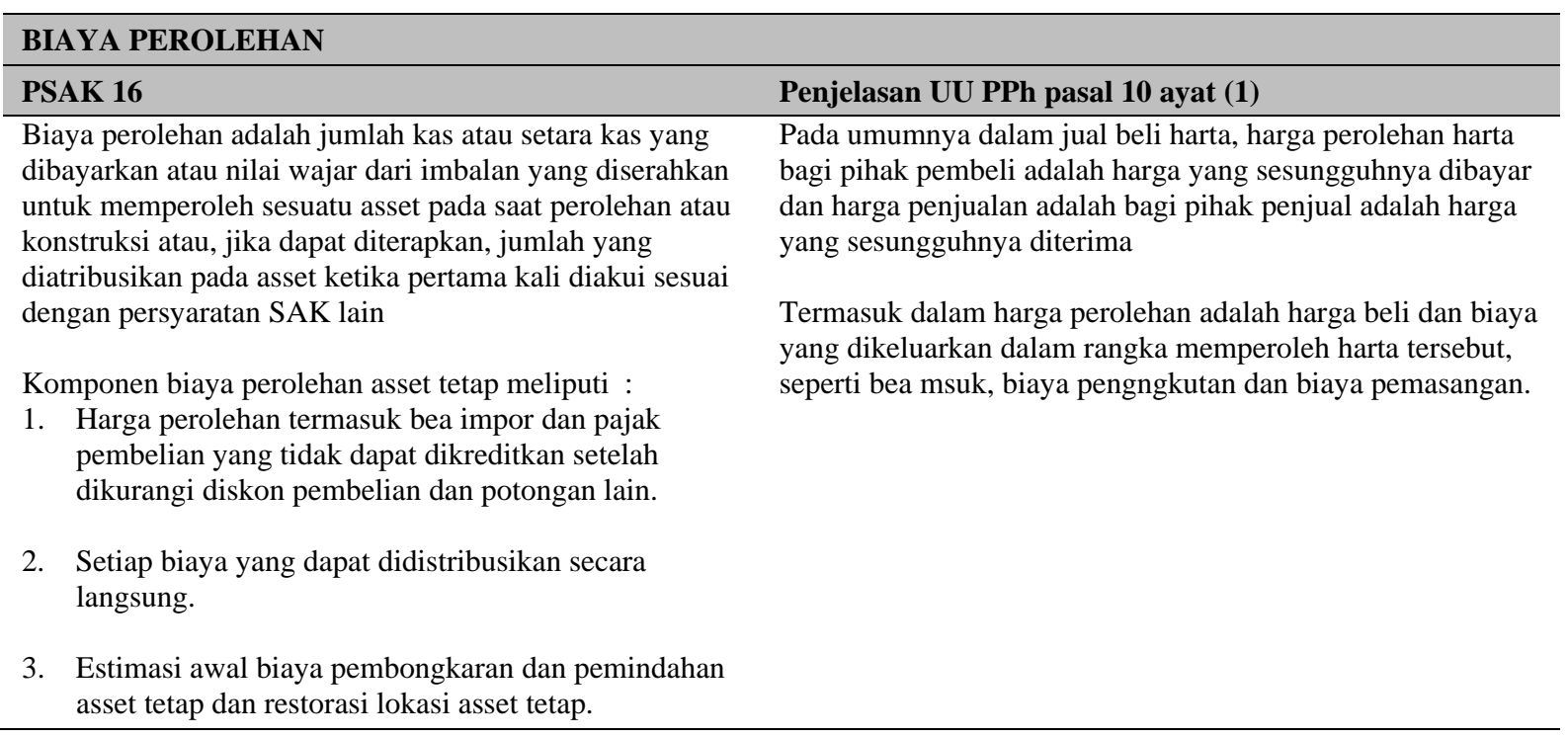


Lessor mengakui asset (piutang sewa pembiayaan) Lessor menilai apakah terjadi penurunan nilai asset pada akhir periode pelaporan dan membentuk cadangan sesuai dngan PSAK 35

Lessor dapat membentuk cadangan penghapusan piutang ragu-ragu yang dapat dikurangkan dari penghasilan bruto maksimal 2,5\% dari rata2 saldo awal dan saldo akhir piutang sewa guna usaha dengan hak opsi (KMK No. 1169/KMK.01/1991 pasal 14)

\begin{tabular}{ll}
\hline DEFINISI & \\
\hline PSAK & Perpajakan \\
\hline
\end{tabular}

\section{Pihak Berelasi}

Anggota keluarga dekat adalah :

- $\quad$ Pasangan hidup dan anak dari individu

- $\quad$ Anak dari pasangan hidup individu

- $\quad$ Tanggungan dari individu atau pasangan hidup individu
Pasal 18 ayat 4 :

- Hubungan keluarga sedarah dalam garis keturunan lurus satu derajat (ayah, ibu, anak)

- Hubungan keluarga sedarah garis keturunan kesamping satu derajat (saudara)

- Keluarga semenda dalam garis keturunan lurus satu derajat (mertua dan anak tiri)

- Hubungan keluarga semenda dalam garis keturunan kesamping satu derajat (ipar)

Entitas dalam satu kelompok usaha.

Kepemilikan penyertaan modal besar atau sama dengan 25\%

Entitas yang mempunyai pengendalian bersama, pengaruh signifikan.

\section{Properti Investasi}

Properti investasi adalah tanah atau bangunan atau bagian dari suatu bangunan atau keduanya yang dikuasai oleh pemilik atau lessee melalui sewa pembiayaan untuk menghasilkan rental atau untuk kenaikan nilai atau keduanya, dan tidak untuk (a) digunakan dalam produksi atau penyediaan barang atau jasa atau untuk tujuan administrative (b) dijual dalam kegiatan usaha sehari2. Properti yang digunakan sendiri adalah property yang dikuasai oleh pemilik atau lessee melalui sewa pembiayaan untuk digunakan dalam produksi atau penyediaan barang atau jasa untuk tujuan administrative
Istilah yang digunakan dalam perpajakan adalah aktiva tetap dan harta berwujud (UU PPh dan PMK 79/2008)

\begin{tabular}{ll}
\hline BIAYA VS KAPITALISASI & \\
\hline PSAK & Perpajakan \\
\hline
\end{tabular}

\section{Penyusutan}

Metode penyusutan dan umur manfaat mencerminkan pola pemakaian atau umur manfaat asset tetap Setiap bagian dari asset tetap yang memiliki biaya perolehan cukup signifikan terhadap total biaya perolehan disusutkan secara terpisah

Penyusutan dimulai saat asset siap digunakan

\section{Nilai Residu}

Jumlah tersusutkan adalah harga perolehan dikurangi nilai residu dibagi dengan umur ekonomis.

Nilai residu adalah estimasi jumlah yang dapat diperoleh entitas saat ini dari pelepasan asset setekah dikurnagi biaya pelepasan, jika asset telah mencapai umur dan kondisi yang diperkirakan pada akhir umur manfaatnya.
Memberikan pengaturan secara spesifik mengenai metode penyusutan dan umur ekonomis aktiva (UU PPh pasal 11 ayat 6)

Penyusutan dimulai pada bulan dilakukannya pengeluaran (UU PPh pasal 11 ayat 1)

Tidak diatur secara spesifik 


\begin{tabular}{|c|c|}
\hline Biaya Riset dan pengembangan (PSAK 26) & \\
\hline $\begin{array}{l}\text { Pengeluaran dalam tahap riset diakui sebagai beban } \\
\text { Pengeluaran dalam tahap pengembangan dikapitalisasi } \\
\text { Jika entitas tidak dapat membedakan tahap penelitian dan } \\
\text { pengembangan maka pengeluarannya diakui sebagai } \\
\text { beban }\end{array}$ & $\begin{array}{l}\text { Biaya penelitian dan pengembangan perusahaan yang } \\
\text { dilakukan di Indonesia boleh dikurangkan dari penghasilan } \\
\text { bruto (deductible epense) UU pasal } 6 \text { ayat } 1 \text { (f) }\end{array}$ \\
\hline
\end{tabular}

Biaya Pinjaman

PSAK 26 : Dikapitalisasi jika biaya pinjaman dapat diatribusikan secara langsung

Dibebankan jika tidak dapat diatribusikan secara langsung

UU PPh pasal 6 ayat 1 (a) :

Besarnya penghasilan kena pajak bagi wajib pajak dalam negeri dan bentuk usaha tetap ditenukan berdasarkan penghasilan bruto dikurangi biaya untuk mendapatkan, menagih dan memelihara penghasilan termasuk biaya pembelian bahan, biaya berkenaan dengan pekerjaan atau jasa termasuk upah, gaji, honorarium, bonus, gratifikasi, dan tunjangan yang diberikan dalam bentuk uang, bunga, sewa/royalty, biaya perjalanan, biaya pengolahan limbah, premi asuransi, biaya administrasi dan pajak kecuali pajak penghasilan.

\begin{tabular}{ll}
\hline PENURUNAN NILAI & \\
\hline SAK & Perpajakan \\
\hline
\end{tabular}

Aset tetap dan asset tak berwujud

Pengukuran setelah pengakuan awal baik menggunakan Tidak diatur secara spesifik model biaya atau model revaluasi, yaitu biaya perolehan (model biaya) atau nilai wajar (model revaluasi) dikurangi akumulasi

Penyusutan dan akumulasi rugi penurunan nilai

\section{Kontrak Asuransi}

Penurunan nilai asset reasuransi diakui jika terdapat bukti objektif dan dampaknya dapat diukur dengan andal

(Ikatan Akuntan Indonesia, 2014:35-37)

Sebagai negara yang memiliki ekonomi terbesar di dunia yang terbesar di dunia yang tergabung dalam G20, dan keikutsertaan Ikatan Akuntan Indonesia dalam International Federation Accounting Committee (IFAC), Indonesia dinilai perlu untuk melakukan konvergensi Standar Akuntansi Keuangan yang selama ini berkiblat ke United States Generally Accepted Accounting Standards ke International Financial Reporting Standards (IFRS). Konvergensi IFRS banyak memberikan manfaat bagi penggunanya. Di antaranya adalah meningkatkan kualitas, kredibilitas, dan kegunaan laporan keuangan yang tentunya dapat memudahkan pemahaman atas laporan keuangan. Laporan keuangan dapat dimengerti oleh pembaca laporan dari negara manapun karena keseragamannya, dan pada akhirnya akan menciptakan efisiensi dalam penyusunan laporan keuangan dan meningkatkan arus investasi kedalam dan keluar melalui pelaporan yang diterima secara internasional.

Setelah dicanangkannya konvergensi IFRS, Indonesia saat ini memiliki 3 SAK yaitu, SAK Umum (berbasis IFRS), SAK ETAP (berjiwa IFRS for SME), dan SAK Syariah (bernafaskan prinsipprinsip syariah di Indonesia). Dampak terdapatnya 3 SAK bagi peraturan perpajakan adalah, dalam peraturan perpajakan, dinyatakan bahwa pembukuan (untuk tujuan pajak) menggunakan Standar Akuntansi Keuangan, kecuali Peraturan Perpajakan menyatakan lain. Hal ini berarti, untuk tujuan pajak, digunakan perlakuan akuntansi sesuai dengan peraturan pajak, kecuali jika tidak diatur dalam peraturan perpajakan, maka pengaturan akuntansinya menggunakan SAK (KUP 28/2007). Kondisi 
terdapatnya 3 SAK, dengan 2 SAK mengatur entitas (SAK Umum dan SAK ETAP) dan 1 SAK mengatur transaksi (SAK Syariah), maka hal ini perlu dicermati oleh regulator perpajakan. Para petugas pajak harus memiliki pemahaman atas SAK ETAP dan SAK Umum.

Jika wajib pajak merupakan entitas berakuntabilitas publik, wajib pajak tersebut akan menggunakan SAK Umum. Oleh karena itu, pemeriksa pajak harus memahami SAK Umum untuk pelakuan akuntansi atas hal-hal yang tidak diatur dalam peraturan pajak. Akan tetapi jika wajib pajak merupakan entitas tanpa akuntabilitas publik, wajib pajak tersebut akan menggunakan SAK ETAP (kecuali jika regulator menyatakan lain). Oleh karena itu, pemeriksa pajak harus memahami SAK ETAP untuk perlakuan akuntansi atas hal-hal yang tidak diatur dalam peraturan pajak. Adanya kemungkinan terjadi perbedaan pengaturan antara SAK ETAP - SAK Umum - Peraturan Perpajakan, maka regulator pajak perlu mengatasi perbedaan penafsiran yang sangat mungkin terjadi di lapangan. Sehingga pemeriksa pajak yang satu dan yang lain tidak akan memiliki penafsiran yang berbeda cukup signifikan atas suatu hal/item (item bisa digunakan dalam standar untuk menggantikan pos, unsur, atau hal-hal lain terkait transaksi/laporan keuangan) tertentu.

Satu hal yang perlu diingat, konvergensi IFRS merupakan kesepakatan pemerintah dalam forum G-20. Konvergensi ini bukan merupakan pekerjaan DSAK-IAI saja. Regulator-regulator seperti Bank Indonesia, Bapepam, dan asosiasi-asosiasi industri telah menyelaraskan regulasi mereka dengan SAK Umum, sebagai bukti dukungan mereka terhadap komitmen pemerintah. Sayangnya, regulator perpajakan merupakan regulator yang dinilai paling lambat dalam menyikapi konvergensi IFRS ini.

Di belahan dunia manapun, hingga saat ini, pengaturan akuntansi selalu berbeda dengan peraturan perpajakan. Hampir tidak ada peraturan akuntansi yang sama dengan peraturan perpajakan. Hal ini dikarenakan tujuan dari akuntansi dan tujuan perpajakan berbeda. Selain itu, prinsip-prinsip dari standar akuntansi dan peraturan perpajakan juga berbeda. Pengaturan dalam standar akuntansi berdasarkan prinsip-prinsip akuntansi dan digunakan untuk pelaporan keuangan bertujuan umum (general purpose financial statement), sedangkan pengaturan dalam peraturan perpajakan berdasarkan aturan (rule based) dan bertujuan khusus (untuk penarikan pajak-kepentingan si penarik pajak/pemerintah). Oleh karena itu, konvergensi IFRS tidak harus membuat peraturan perpajakan juga ikut konvergen (apalagi peraturan perpajakan induknya adalah undang-undang, yang mana jika ingin mengubah undang-undang proses birokrasinya sangat lama dan berbelit di DPR).

Direktorat Jendral Pajak sendiri belum menetapkan waktu penerapan IFRS. Menurut Dirjen Pajak, tidak hanya di Indonesia, hampir seluruh negara melakukan tindakan serupa dan belum siap menerapkan IFRS di bidang perpajakan. Alasannya sangat mendasar karena muncul kekhawatiran bila IFRS diberlakukan di sektor perpajakan, pendapatan dari sektor ini akan menurun. Walaupun perbedaan antara SAK dan Peraturan Perpajakan tidak akan pernah bisa dihilangkan, sebaiknya regulator perpajakan tetap melakukan tindakan untuk meminimalkan bentang perbedaan antara SAK yang ada saat ini (SAK Umum \& ETAP) dengan Peraturan Perpajakan. Hal ini disebabkan SAK sudah berkembang sangat pesat, sedangkan Peraturan Perpajakan sangat tertinggal jauh dalam hal penggunaan dasar akuntansinya.

\section{SIMPULAN}

Berdasarkan pembahasan mengenai kemungkinan harmonisasi SAK dengan peraturan perpajakan, maka penelitian ini menyimpulkan sebagai berikut. Pertama, terdapat perbedaan antara perpajakan dan IFRS, di antaranya adalah dalam metode perhitungan aset tetap, adanya beberapa pospos yang tidak diakui oleh pajak dalam laporan laba rugi komprehensif, pengungkapan pihak-pihak yang memiliki hubungan istimewa, pengaruh perubahan nilai tukar valuta asing, operating lease, goodwill, dan sebagainya. Kedua, selalu ada perbedaan antara standar akuntansi dan peraturan 
perpajakan. Hal ini disebabkan tujuan dari akuntansi dan tujuan perpajakan berbeda. Selain itu, prinsip-prinsip dari standar akuntansi dan peraturan perpajakan juga berbeda. Namun walaupun perbedaan antara SAK dan Peraturan Perpajakan tidak akan pernah bisa dihilangkan, sebaiknya regulator perpajakan tetap melakukan tindakan untuk meminimalkan bentang perbedaan antara SAK yang ada saat ini (SAK Umum \& ETAP) dengan Peraturan Perpajakan. Ketiga, konvergensi IFRS tidak memberikan pengaruh terhadap pelaporan pajak karena laporan keuangan fiskal mengacu pada aturan pajak (Undang-Undang, Peraturan Menteri Keuangan, Peraturan Direktorat Jenderal, dll) yang berbeda dengan PSAK/IFRS/US GAAP dan sebagainya (kecuali yang tidak diatur dalam perpajakan).

Keempat, kita dituntut belajar terus menerus menyesuaikan perkembangan standar akuntansi dan peraturan perpajakan, yang masing-masing berjalan dengan arahnya sendiri-sendiri. Kelima, pihak otoritas yang terkait dengan standar akuntansi dan Direktorat Jenderal Pajak (DJP) secara berkesinambungan melakukan upaya-upaya untuk meminimalkan dampat negatif atau merugikan baik wajib pajak maupun negara yang dalam hal pengamanan penerimaan negara dan upaya kerjasama itu membuahkan hasil dengan dibentuknya kompartemen khusus tepatnya pada tanggal 13 Maret 2014 telah dibentuk kompartemen Akuntan Pajak oleh Ikatan akuntan Indonesia.

\section{DAFTAR PUSTAKA}

Augustyas, D. (2011, 25 Oktober). Standar Akuntansi Keuangan. Diakses dari dhiasitsme.wordpress.com/2011/10/25/standar-akuntansi-keuangan-sak/

Ikatan Akuntan Indonesia. (2014). Majalah Akuntan Indonesia. April - Mei, 2014.

Ikatan Akuntan Indonesia. (n.d.). Standar Akuntansi Keuangan. Jakarta: Salemba Empat International Financial Reporting System. (2010). New Jersey: John Wiley \& Sons.

Kieso, D. E., Weygandt, J. J., \& Warfield, T. D. (n.d.). Intermediate Accounting: IFRS Edition. New Jersey: John Wiley \& Sons.

Mouri,M. (2012, 21 Agustus). Konvergensi IFRS Dan Pengaruhnya ke Pajak. Diakses dari mahonakmohak.wordpress.com/2012/08/21/konvergensi-ifrs-dan-pengaruhnya-ke-pajak/ 